\title{
Papers
}

\section{Heterogeneity of coronary heart disease risk factors in Indian, Pakistani, Bangladeshi, and European origin populations: cross sectional study}

\author{
Raj Bhopal, Nigel Unwin, Martin White, Julie Yallop, Louise Walker, K G M M Alberti, Jane Harland, \\ Sheila Patel, Naseer Ahmad, Catherine Turner, Bill Watson, Dalvir Kaur, Anna Kulkarni, Mike Laker, \\ Anna Tavridou
}

\begin{abstract}
Objective To compare coronary risk factors and disease prevalence among Indians, Pakistanis, and Bangladeshis, and in all South Asians (these three groups together) with Europeans.

Design Cross sectional survey.

Setting Newcastle upon Tyne.

Participants 259 Indian, 305 Pakistani, 120

Bangladeshi, and 825 European men and women aged 25-74 years.

Main outcome measures Social and economic circumstances, lifestyle, self reported symptoms and diseases, blood pressure, electrocardiogram, and anthropometric, haematological, and biochemical measurements.

Results There were differences in social and economic circumstances, lifestyles, anthropometric measures and disease both between Indians, Pakistanis, and Bangladeshis and between all South Asians and Europeans. Bangladeshis and Pakistanis were the poorest groups. For most risk factors, the Bangladeshis (particularly men) fared the worst: smoking was most common (57\%) in that group, and Bangladeshis had the highest concentrations of triglycerides $(2.04 \mathrm{mmol} / \mathrm{l})$ and fasting blood glucose (6.6 mmol/l) and the lowest concentration of high density lipoprotein cholesterol $(0.97 \mathrm{mmol} / \mathrm{l})$. Blood pressure, however, was lowest in Bangladeshis. Bangladeshis were the shortest (men $164 \mathrm{~cm}$ tall $v$ $170 \mathrm{~cm}$ for Indians and $174 \mathrm{~cm}$ for Europeans). A higher proportion of Pakistani and Bangladeshi men had diabetes (22.4\% and $26.6 \%$ respectively) than Indians (15.2\%). Comparisons of all South Asians with Europeans hid some important differences, but South Asians were still disadvantaged in a wide range of risk factors. Findings in women were similar. Conclusion Risk of coronary heart disease is not uniform among South Asians, and there are important differences between Indians, Pakistanis, and Bangladeshis for many coronary risk factors. The belief that, except for insulin resistance, South Asians have lower levels of coronary risk factors than Europeans is incorrect, and may have arisen from
\end{abstract}

combining ethnic subgroups and examining a narrow range of factors.

\section{Introduction}

Coronary heart disease is apparently commoner in South Asians in Britain than in the general population ${ }^{1}$ despite lower levels of several classic coronary risk factors. ${ }^{2}{ }^{3}$ Insulin resistance is proposed to be the underlying factor in high rates of coronary heart disease among South Asians worldwide and has been related to lack of exercise and obesity. Bhopal, and Shaukat and de Bono, however, emphasised a wide range of risk factors including smoking and poverty. ${ }^{45}$ Williams et al concluded that South Asians had a higher prevalence of a broad range of non-biochemical risk factors than the general population. ${ }^{6}$ Nazroo showed that the prevalence of self reported coronary heart disease was higher in Bangladeshis and Pakistanis combined, and lower in Indians, than in the white population after standard of living was adjusted for. ${ }^{7}$ The Newcastle heart project compared coronary heart disease risk factors in Indians, Pakistanis, and Bangladeshis and also compared South Asians as a whole with Europeans. ${ }^{89}$

\section{Participants and methods}

The methods and some data on the European study have been published, ${ }^{89}$ and more detail is available on the $B M J$ 's website. South Asians are defined as Newcastle residents with ancestral origins in India, Pakistan, or Bangladesh and who had three or more grandparents born there. Indians, Pakistanis, and Bangladeshis self identified as such at interview, using 1991 census categories of ethnic group. Europeans are defined as Newcastle residents with ancestral origins in European countries and were identified by excluding people from ethnic minority populations. In referring to published work we generally use the authors' terms (white, general population, etc).

\section{Sample}

We selected European subjects from the 6448 people identified from the family health services authority
Department of
Epidemiology and
Public Health,
Medical School,
University of
Newcastle,
Newcastle upon
Tyne NE2 4HH
Raj Bhopal,
professor available on the $B M J$ 's website

www.bmj.com 
Department of Medicine, Medical School, University of Newcastle K G M M Alberti, professor

Department of Clinical

Biochemistry,

Medical School,

University of

Newcastle

Mike Laker,

reader

Anna Tavridou, PhD student

Correspondence to: R Bhopal Public Health Sciences, Medical School, Edinburgh EH8 9AG Raj.Bhopal@ed. ac.uk register for the Newcastle health and lifestyle survey (NHLS). ${ }^{8}$ People with South Asian sounding names were selected from the full register. ${ }^{10}$ The age group studied was 25-74 years. The sampling frame was divided into 10 year age and sex strata, and equal numbers from each stratum randomly selected. Europeans were screened between April 1993 and October 1994 and South Asians between May 1995 and March 1997.

\section{Biochemical measurements}

Participants not requiring insulin fasted from 2200 the night before attending a clinic at Royal Victoria Infirmary, Newcastle. Venous blood was taken for the measurement of lipids (including Lp(a) lipoprotein), insulin, and glucose. Subjects not reporting a diagnosis of diabetes took a standard World Health Organisation oral glucose tolerance test and glucose tolerance was based on the 2 hour result, as previously described. ${ }^{9}$ Insulin was measured using an enzyme linked immunosorbent assay (DAKO Diagnostics, Ely).

\section{Anthropometric measurements, blood pressure, pulse, and electrocardiography}

Height, weight, waist and hip circumference, and blood pressure were measured as previously described for the European subjects. ${ }^{8}$ We used established criteria to define risk factors for coronary heart disease. ${ }^{11}{ }^{12}$ Participants with a carbon monoxide concentration $>8 \mathrm{ppm}$ on the Bedfast Smokerlyzer carbon monoxide monitor ${ }^{13}$ and who did not admit to smoking were counted as carbon monoxide adjusted smokers. A 12 lead resting electrocardiogram was recorded and Minnesota coded by two independent coders. ${ }^{8}$

\section{Questionnaire}

Participants completed a questionnaire including questions on state of health, health behaviour, and socioeconomic circumstances. Europeans self com-

Table 1 Background, social, and economic characteristics of men in study. Values are numbers (percentages) and denominators within 10 of $n$ unless stated otherwise

\begin{tabular}{|c|c|c|c|c|c|}
\hline & $\begin{array}{c}\text { Indian } \\
(\mathrm{n}=105)\end{array}$ & $\begin{array}{l}\text { Pakistani } \\
(\mathrm{n}=156)\end{array}$ & $\begin{array}{l}\text { Bangladeshi } \\
\quad(n=64)\end{array}$ & $\begin{array}{l}\text { All South } \\
\text { Asian } \\
(\mathrm{n}=325)\end{array}$ & $\begin{array}{c}\text { European } \\
(\mathrm{n}=425)\end{array}$ \\
\hline Mean (SD) age (years) & $50.73(13.2)$ & $52.21(12.9)$ & $47.69(13.1)$ & $50.84(13.1)$ & $54.17(13.1)$ \\
\hline \multicolumn{6}{|l|}{ Birth place: } \\
\hline Indian subcontinent & $84(80)$ & $146(94)$ & $64(100)$ & $294(90)$ & - \\
\hline United Kingdom & $12(11)$ & $8(5)$ & - & $20(6)$ & - \\
\hline Other & $9(9)$ & $2(1)$ & - & $11(3)$ & - \\
\hline \multicolumn{6}{|l|}{ Year moved to UK $(\mathrm{n}=297)^{\star}$ : } \\
\hline Before 1962 & $34(42)$ & $63(44)$ & $14(23)$ & $115(39)$ & - \\
\hline $1962-75$ & $37(41)$ & $59(41)$ & $34(55)$ & $130(44)$ & - \\
\hline After 1975 & $16(18)$ & $22(15)$ & $14(23)$ & $52(18)$ & - \\
\hline \multicolumn{6}{|l|}{ Education ( $\mathrm{n}=414$, European): } \\
\hline None & $4(4)$ & $14(9)$ & $6(9)$ & $24(7)$ & $2(0.5)$ \\
\hline Primary & $9(9)$ & $25(16)$ & $13(20)$ & $47(15)$ & $79(19)$ \\
\hline Secondary & $31(30)$ & $54(35)$ & $33(52)$ & $118(36)$ & $248(59)$ \\
\hline Further education & $22(21)$ & $37(24)$ & $7(11)$ & $66(20)$ & $26(6)$ \\
\hline Higher & $37(35)$ & $24(15)$ & $5(8)$ & $66(20)$ & $47(12)$ \\
\hline \multicolumn{6}{|l|}{$\begin{array}{l}\text { Social class ( } n=311 \text {, S Asian; } \\
\text { 388 European): }\end{array}$} \\
\hline I, II, or IIIN & $70(70)$ & $71(48)$ & $16(26)$ & $157(51)$ & $144(43)$ \\
\hline IIIM, IV, or V & $30(30)$ & $78(52)$ & $46(74)$ & $154(50)$ & $194(57)$ \\
\hline $\begin{array}{l}\text { Median (interquartile range) } \\
\text { income (£000s) ( } n=307, \\
\text { S Asian; 391, European) }\end{array}$ & $5.1(3.0-10.8)$ & $3.4(2.2-4.4)$ & $2.3(1.6-3.4)$ & $3.4(2.2-5.5)$ & $5.5(3.8-8.0)$ \\
\hline
\end{tabular}

pleted the questionnaire. The questionnaire was translated into four South Asian languages then independently retranslated into English, with translators and researchers conferring and agreeing on equivalence of meaning. South Asian interviewers completed the questionnaire in the participants' homes and preferred languages. The Rose chest pain questionnaire was interpreted as recommended..$^{14}$

\section{Analysis of data}

We analysed data using SPSS/PC + version 6. Direct age standardisation was to the 1991 England and Wales population. Differences between Europeans and South Asians for continuous variables were assessed by independent samples $t$ tests, and differences between Indians, Pakistanis and Bangladeshis by analysis of variance. Income data, for men only, were adjusted for household composition using the formula: income/ $(1+0.7 \times$ adults $+0.5 \times$ children $) \cdot{ }^{15}$ As triglycerides, Lp(a) lipoprotein, and insulin had skewed distributions $\log$ transformations were used in analysis and geometric means are presented. For categorical variables, age adjusted variances were calculated.

\section{Ethics}

Newcastle upon Tyne joint ethics committee approved the study. Informed consent was obtained from participants. If participants did not consent to three venepunctures, our priority was baseline and then 2 hour samples. For example, 20 Indian, 26 Pakistani, and 22 Bangladeshi women did not consent to a 2 hour sample.

\section{Results}

Of 2160 people with South Asian sounding names, 1050 people were eligible and contacted; 288 refused and 53 completed only the interview, leaving 709 (67.5\% of 1050). Of these, 684 classified themselves as Indian, Pakistani, or Bangladeshi. Of 1744 people sampled from the Newcastle health and lifestyle survey, 1308 were contacted and 840 were screened (64.2\%). Fourteen were South Asian and one of African origin, leaving 825 Europeans.

\section{Population characteristics}

Table 1 shows Bangladeshi men were the youngest group and the most recent immigrants (data on BMJ's website). Indians were most, and Bangladeshis least, educated. Indians were most likely to be in social classes I, II and IIIN (70\%) and Bangladeshis least (26\%). Europeans and Indians had the highest median income and Bangladeshis the lowest. Table 2 shows similar findings in women.

\section{Lifestyle}

Table 3 shows the highest prevalence of smoking was in Bangladeshi men. Pakistanis and Indians were most likely to eat fruit or vegetables daily. Few Pakistanis and Bangladeshis drank alcohol; most Indians did. Indians were the most physically active South Asians, Bangladeshis the least. Large differences existed between Europeans and South Asians except in smoking.

Few Indian, Pakistani, or Bangladeshi women smoked or drank alcohol (table 3). Daily consumption of fruit or vegetables was commoner in Indians than in 
Bangladeshis and Europeans. Bangladeshis were the least, and the Indians the most, physically active South Asians. The differences between Europeans and South Asians were large.

\section{Prevalence of clinical problems}

Table 4 shows non-significant variation in diabetes between the three male South Asian groups, which collectively had a five times higher prevalence of diabetes than Europeans. There were important differences between the three South Asian groups in total cholesterol:high density lipoprotein cholesterol ratio and triglyceride concentration. South Asians had lower high density lipoprotein cholesterol concentration, higher total cholesterol:high density lipoprotein cholesterol ratio and higher triglyceride concentrations than Europeans.

Obesity was commoner in Pakistanis and Indians than in Bangladeshis. Differences in central obesity between South Asian groups were small. Waist:hip ratios of $\geqslant 0.95$ were commoner in South Asians than Europeans. Differences in hypertension between Indians, Pakistanis and Bangladeshis were not significant, but hypertension was least common in Bangladeshis and less common in South Asians than Europeans.

Prevalence of Rose angina was similar among the South Asian groups and between them and Europeans. Possible myocardial infarction was higher (not significant) in Bangladeshis than Indians or Pakistanis. Evidence of coronary heart disease on electrocardiography was similar among the three South Asian groups, which combined had more probable heart disease than Europeans.

A higher propertion of Indian women had diabetes than Pakistanis and Bangladeshis (not significant) Diabetes was four to five times commoner in South Asians than in Europeans (table 5). Among South Asians, Bangladeshis were most likely to have low high density lipoprotein cholesterol concentration, high cholesterol:high density lipoprotein cholesterol ratio and high triglyceride concentrations. South Asians had a less favourable lipid profile than Europeans with the exception of total cholesterol.
Table 2 Background, social, and economic characteristics of women in study. Values are numbers (percentages) and denominators with 10 of $n$ unless stated otherwise

\begin{tabular}{|c|c|c|c|c|c|}
\hline & $\begin{array}{c}\text { Indian } \\
(\mathrm{n}=154)\end{array}$ & $\begin{array}{l}\text { Pakistani } \\
(n=149)\end{array}$ & $\begin{array}{l}\text { Bangladeshi } \\
\quad(n=56)\end{array}$ & $\begin{array}{l}\text { All South } \\
\text { Asian } \\
(\mathrm{n}=359)\end{array}$ & $\begin{array}{l}\text { European } \\
(n=399)\end{array}$ \\
\hline Mean (SD) age (years) & $52.40(11.7)$ & $48.33(12.0)$ & $48.14(12.7)$ & $50.05(12.1)$ & $54.03(12.9)$ \\
\hline \multicolumn{6}{|l|}{ Birth place: } \\
\hline Indian subcontinent & $137(89)$ & $137(93)$ & $54(100)$ & $328(93)$ & - \\
\hline United Kingdom & $9(6)$ & $9(6)$ & - & $18(5)$ & - \\
\hline Other & $7(5)$ & $1(1)$ & - & $8(2)$ & - \\
\hline \multicolumn{6}{|l|}{ Year moved to UK $(n=323)^{*}$ : } \\
\hline Before 1962 & 47 (34) & 14 (11) & - & $61(19)$ & - \\
\hline $1962-75$ & $59(43)$ & $77(58)$ & $13(25)$ & $149(46)$ & - \\
\hline After 1975 & $31(23)$ & $42(32)$ & $40(76)$ & $113(35)$ & - \\
\hline \multicolumn{6}{|l|}{ Education ( $\mathrm{n}=364$, European): } \\
\hline None & $29(19)$ & $62(42)$ & $19(35)$ & $110(31)$ & $1(0)$ \\
\hline Primary & $26(17)$ & $22(15)$ & $17(31)$ & $65(18)$ & $54(14)$ \\
\hline Secondary & $42(27)$ & $37(25)$ & $16(29)$ & $95(27)$ & $245(62)$ \\
\hline Further education & $32(21)$ & $17(12)$ & $3(6)$ & $52(15)$ & $33(8)$ \\
\hline Higher & $20(13)$ & $9(6)$ & 一 & $29(8)$ & $31(8)$ \\
\hline \multicolumn{6}{|c|}{ Social class ( $\mathrm{n}=265, \mathrm{~S}$ Asian; 295, European): } \\
\hline I, II, or IIIN & $92(73)$ & $71(64)$ & $6(21)$ & $169(64)$ & $152(52)$ \\
\hline IIIM, IV, or V & $34(27)$ & $40(36)$ & $22(79)$ & $96(36)$ & $143(49)$ \\
\hline \multicolumn{6}{|l|}{ Housing: } \\
\hline Homeowners & $145(95)$ & $123(84)$ & $26(46)$ & $294(83)$ & $275(70)$ \\
\hline $\begin{array}{l}\text { Overcrowding (>1 person/room) } \\
\text { ( } n=343 \text {, S Asian; 383, European) }\end{array}$ & $23(16)$ & $41(29)$ & $32(57)$ & $96(28)$ & $4(1)$ \\
\hline Problems with area & $26(17)$ & $20(14)$ & $5(9)$ & $51(15)$ & $65(17)$ \\
\hline
\end{tabular}

${ }^{*}$ From subset of 336

Obesity was commoner in Indian and Pakistani women than in Bangladeshis. High waist:hip ratios were commoner in Pakistanis and Bangladeshis, and about four times commoner in South Asians than Europeans.

Coronary heart disease was too rare for reliable comparisons among South Asian groups, but on both questionnaire and electrocardiography there was slightly less coronary heart disease in Bangladeshis than Indians and Pakistanis. South Asians had more possible myocardial infarction on questionnaire and probable coronary heart disease on electrocardiography than Europeans.

Table 6 shows that Bangladeshi men and women had the highest risk profiles for 9 of 15 coronary heart

Table 3 Smoking, diet, alcohol consumption, and exercise among men and women. Values are numbers (percentages) weighted to 1991 England and Wales population. Denominators are within 10 of $n$ unless stated otherwise

\begin{tabular}{lcccccc} 
& Indian & Pakistani & Bangladeshi & P value & $\begin{array}{c}\text { All South } \\
\text { Asian }\end{array}$ & $\begin{array}{c}\text { 95\% Cl for } \\
\text { European }\end{array}$ \\
\hline difference
\end{tabular}


Table 4 Prevalence of glucose intolerance, dyslipidaemia, obesity, hypertension, and coronary heart disease in men. Values are numbers (percentages) age adjusted to 1991 England and Wales population

\begin{tabular}{|c|c|c|c|c|c|c|c|}
\hline & $\begin{array}{c}\text { Indian } \\
(\mathrm{n}=105)\end{array}$ & $\begin{array}{c}\text { Pakistani } \\
(\mathrm{n}=156)\end{array}$ & $\begin{array}{l}\text { Bangladeshi } \\
\quad(n=64)\end{array}$ & $P$ value & $\begin{array}{l}\text { All South } \\
\text { Asian } \\
(n=325)\end{array}$ & $\begin{array}{l}\text { European } \\
(n=425)\end{array}$ & $\begin{array}{l}95 \% \mathrm{Cl} \text { for } \\
\text { difference }\end{array}$ \\
\hline \multicolumn{8}{|l|}{ Glucose intolerance: } \\
\hline $\begin{array}{l}\text { Impaired glucose tolerance ( } \mathrm{n}=291, \mathrm{~S} \text { Asian; } 413 \text {, } \\
\text { European) }\end{array}$ & $17(17)$ & $33(24)$ & $9(16)$ & 0.569 & $59(20)$ & $55(13)$ & 1.55 to 12.6 \\
\hline All diabetes & $16(15)$ & $35(22)$ & $17(27)$ & 0.174 & $68(20)$ & $16(4)$ & 12.2 to 20.5 \\
\hline \multicolumn{8}{|l|}{ Dyslipidaemia: } \\
\hline Total cholesterol $\geqslant 6.5 \mathrm{mmol} / \mathrm{l}$ & $19(19)$ & $34(22)$ & $9(14)$ & 0.410 & $63(19)$ & $95(22)$ & -8.88 to 2.78 \\
\hline $\begin{array}{l}\text { HDL cholesterol } \leqslant 0.9 \mathrm{mmol} / \mathrm{l}(\mathrm{n}=301, \mathrm{~S} \text { Asian; } 410 \\
\text { European) }\end{array}$ & $16(17)$ & $44(30)$ & $30(52)$ & $<0.001$ & $90(30)$ & $53(13)$ & 10.9 to 22.9 \\
\hline $\begin{array}{l}\text { Total cholesterol:HDL cholesterol } \geqslant 5 \text { ( } n=301 \\
\text { S Asian; } 408 \text { European) }\end{array}$ & $37(40)$ & $79(53)$ & $41(71)$ & 0.001 & $157(53)$ & $140(34)$ & 11.2 to 25.8 \\
\hline Triglycerides $\geqslant 1.7 \mathrm{mmol} / \mathrm{l}$ & $45(44)$ & $85(54)$ & $44(69)$ & 0.006 & $174(55)$ & $153(37)$ & 11.0 to 25.3 \\
\hline \multicolumn{8}{|l|}{ Overweight: } \\
\hline Body mass index $\geqslant 25$ & $68(66)$ & $107(69)$ & $30(47)$ & 0.007 & $213(63)$ & $250(56)$ & -0.8 to 15.1 \\
\hline Waist:hip $\geqslant 0.95$ & $59(57)$ & $95(61)$ & $40(63)$ & 0.746 & $193(60)$ & $115(27)$ & 25.9 to 39.4 \\
\hline $\begin{array}{l}\text { Reported hypertension or blood pressure } \\
>160 / 95 \mathrm{~mm} \mathrm{Hg} \text { at screening }\end{array}$ & $15(14)$ & $14(9)$ & $4(6)$ & 0.202 & $32(10)$ & $76(18)$ & -12.7 to -3.2 \\
\hline \multicolumn{8}{|l|}{ Rose questionnaire: } \\
\hline Angina ( $n=325$, S Asian; 407, European) & $4(4)$ & $4(3)$ & $2(3)$ & * & $10(3)$ & $24(6)$ & -6.11 to 0.32 \\
\hline $\begin{array}{l}\text { Possible myocardial infarction ( } n=324 \text {, S Asian; } \\
\text { 400, European) }\end{array}$ & $12(11)$ & $14(9)$ & $15(24)$ & 0.103 & $41(12)$ & $39(10)$ & -2.32 to 7.41 \\
\hline \multicolumn{8}{|l|}{ Electrocardiogram: } \\
\hline Possible coronary heart disease & $14(13)$ & $21(14)$ & $9(14)$ & 0.84 & $44(14)$ & $43(10)$ & -1.20 to 7.63 \\
\hline Probable coronary heart disease & $4(4)$ & $10(7)$ & $5(8)$ & 0.512 & $19(6)$ & $8(2)$ & 1.43 to 5.95 \\
\hline
\end{tabular}

disease risk factors. Indians were advantaged by comparison. South Asians had higher levels than Europeans in 10 of 15 factors.

\section{Discussion}

Newcastle South Asians, mostly from the north of the Indian subcontinent and Sylhet, have a mix of religions, languages, and lifestyles, similar to those described nationally. ${ }^{16}$ Our findings that coronary risk factors patterns are different in Indians, Pakistanis, and Bangladeshis and that South Asians combined have higher levels than Europeans, probably apply elsewhere. The heterogeneity of South Asian populations has too rarely been acknowledged in the context of coronary heart disease. ${ }^{2}{ }^{17-20} \mathrm{New}$ and larger studies are needed to assess whether the incidence and prevalence of coronary heart disease and diabetes differs between Indians, Pakistanis, and Bangladeshis as suggested here and elsewhere. ${ }^{17}$

Table 5 Prevalence of glucose intolerance, dyslipidaemia, obesity, hypertension, and coronary heart disease in women. Values are numbers (percentages) age adjusted to 1991 England and Wales population

\begin{tabular}{|c|c|c|c|c|c|c|c|}
\hline & $\begin{array}{c}\text { Indian } \\
(\mathrm{n}=154)\end{array}$ & $\begin{array}{c}\text { Pakistani } \\
(\mathrm{n}=149)\end{array}$ & $\begin{array}{l}\text { Bangladeshi } \\
(\mathrm{n}=56)\end{array}$ & $P$ value & $\begin{array}{c}\text { All South } \\
\text { Asian } \\
(\mathrm{n}=359)\end{array}$ & $\begin{array}{c}\text { European } \\
(\mathrm{n}=399)\end{array}$ & $\begin{array}{l}95 \% \mathrm{Cl} \text { for } \\
\text { difference }\end{array}$ \\
\hline \multicolumn{8}{|l|}{ Glucose intolerance: } \\
\hline $\begin{array}{l}\text { Impaired glucose tolerance ( } \mathrm{n}=305, \mathrm{~S} \text { Asian; } 380 \text {, } \\
\text { European) }\end{array}$ & $27(19)$ & $32(25)$ & $11(34)$ & 0.170 & $70(24)$ & $47(12)$ & 6.16 to 17.8 \\
\hline All diabetes & $20(13)$ & $34(23)$ & $13(23)$ & 0.057 & $68(18)$ & $15(4)$ & 10.2 to 18.9 \\
\hline \multicolumn{8}{|l|}{ Dyslipidaemia: } \\
\hline Total cholesterol $\geqslant 6.5 \mathrm{mmol} / \mathrm{l}$ & $30(19)$ & $28(19)$ & $2(4)$ & 0.033 & $61(17)$ & $86(22)$ & -9.95 to 0.45 \\
\hline $\begin{array}{l}\text { HDL cholesterol } \leqslant 0.9 \mathrm{mmol} / \mathrm{l}(\mathrm{n}=345, \mathrm{~S} \text { Asian; } 385 \text {, } \\
\text { European) }\end{array}$ & $8(5)$ & $20(14)$ & $10(21)$ & 0.003 & $38(11)$ & $7(2)$ & 6.00 to 13.0 \\
\hline $\begin{array}{l}\text { Total cholesterol:HDL cholesterol } \geqslant 5(n=345 \text {, } \\
\text { S Asian; } 392 \text { European) }\end{array}$ & $31(20)$ & $43(29)$ & $18(38)$ & 0.032 & $92(26)$ & $53(14)$ & 6.74 to 17.9 \\
\hline Triglycerides $\geqslant 1.7 \mathrm{mmol} / \mathrm{l}$ & $57(37)$ & $59(40)$ & $29(59)$ & 0.020 & $145(41)$ & $119(30)$ & 4.26 to 17.4 \\
\hline \multicolumn{8}{|l|}{ Overweight: } \\
\hline Body mass index $\geqslant 25$ & $107(69)$ & $98(66)$ & $32(58)$ & 0.311 & $231(66)$ & $207(52)$ & 6.20 to 19.9 \\
\hline Body mass index $\geqslant 30$ & $59(38)$ & $50(34)$ & $8(15)$ & 0.006 & $117(32)$ & $63(16)$ & 10.3 to 22.2 \\
\hline Waist:hip $\geqslant 0.85$ & $65(42)$ & $88(60)$ & $29(55)$ & 0.006 & $182(53)$ & $66(17)$ & 30.2 to 43.3 \\
\hline $\begin{array}{l}\text { Reported hypertension or blood presssure } \\
>160 / 95 \mathrm{~mm} \mathrm{Hg} \text { at screening }\end{array}$ & $23(15)$ & $18(12)$ & $3(5)$ & 0.164 & $44(14)$ & $47(12)$ & -2.20 to 6.13 \\
\hline \multicolumn{8}{|l|}{ Rose questionnaire: } \\
\hline Angina ( $\mathrm{n}=358$, S Asian; 372, European) & $11(7)$ & $2(1)$ & - & 0.007 & $13(4)$ & $18(5)$ & -4.41 to 1.47 \\
\hline $\begin{array}{l}\text { Possible myocardial infarction ( } n=354, \text { S Asian; } 373 \text {, } \\
\text { European) }\end{array}$ & $24(16)$ & $27(18)$ & $8(14)$ & 0.728 & $59(17)$ & $24(7)$ & 5.48 to 15.28 \\
\hline \multicolumn{8}{|l|}{ Electrocardiography: } \\
\hline Possible coronary heart disease & $29(19)$ & $30(20)$ & $7(13)$ & 0.051 & $66(17)$ & $55(14)$ & -1.65 to 9.02 \\
\hline Probable coronary heart disease & $12(8)$ & $4(3)$ & - & 0.023 & $16(5)$ & $4(1)$ & 1.88 to 6.83 \\
\hline
\end{tabular}


Table 6 Ethnic groups with highest risk profiles for various coronary heart disease risk factors

\begin{tabular}{|c|c|c|c|c|}
\hline \multirow[b]{2}{*}{ Risk factor } & \multicolumn{2}{|c|}{ Women } & \multicolumn{2}{|l|}{ Men } \\
\hline & $\begin{array}{l}\text { Indians, Pakistanis, } \\
\text { Bangladeshis, and Europeans }\end{array}$ & $\begin{array}{l}\text { South Asians and } \\
\text { Europeans }\end{array}$ & $\begin{array}{l}\text { Indians, Pakistanis, } \\
\text { Bangladeshis, and Europeans }\end{array}$ & $\begin{array}{l}\text { South Asians and } \\
\text { Europeans }\end{array}$ \\
\hline $\begin{array}{l}\text { Economic circumstances (education, social } \\
\text { class, overcrowding, income) }\end{array}$ & Bangladeshi & South Asian & Bangladeshi & European \\
\hline Smoking & European & European & Bangladeshi & South Asian \\
\hline Fruit and vegetable consumption & Bangladeshi & European & European & European \\
\hline No cardioprotective level of alcohol & Bangladeshi & South Asian & Bangladeshi & South Asian \\
\hline Level of exercise & Bangladeshi & South Asian & Bangladeshi & South Asian \\
\hline Height & Bangladeshi & South Asian & Bangladeshi & South Asian \\
\hline Obesity (body mass index) & Indian & European & Indian & South Asian \\
\hline Impaired glucose tolerance & Bangladeshi & South Asian & Pakistani & South Asian \\
\hline Diabetes & Bangladeshi & South Asian & Bangladeshi & South Asian \\
\hline HDL cholesterol & Bangladeshi & South Asian & Bangladeshi & South Asian \\
\hline LDL cholesterol & European & South Asian & European & European \\
\hline Triglycerides & Bangladeshi & South Asian & Bangladeshi & South Asian \\
\hline Lp(a) lipoprotein & Pakistani & South Asian & Bangladeshi & South Asian \\
\hline Fibrinogen & Indian & European & Pakistani & European \\
\hline Blood pressure & European/Indian & European & European & European \\
\hline
\end{tabular}

We acknowledge potential bias because Europeans self completed the questionnaire whereas South Asians had home interviews and Europeans and South Asians were studied sequentially. These decisions were pragmatic and resource driven; self completion of questionnaires by South Asians was inappropriate, and interviewing Europeans beyond our resources. The South Asian study needed staff with appropriate languages and cultural knowledge so screening them separately was more practical. Changes in disease and risk factors would be small between 1993-4 (European study, midpoint January 1994) and 1995-7 (South Asian study, midpoint August 1996). This paper, moreover, focuses on variations among South Asian subgroups, for whom data were collected simultaneously.

Hypotheses for the high rates of coronary heart disease in South Asians include the use of ghee and other cooking oils ${ }^{21}$; non-vegetarian diets ${ }^{22}$; subclinical hypothyroidism ${ }^{23}$; stress, racism, and poverty ${ }^{6}$; deprivation in infancy and childhood ${ }^{64}$; and insulin resistance. ${ }^{217}$ The insulin resistance hypothesis has overshadowed other explanations. $^{3}{ }^{1725}$ This study draws attention to a wide range of risk factors and shows that combining data for South Asians is misleading.

\section{Key messages}

- South Asians have more coronary heart disease than Europeans despite apparently lower levels of risk factors

- This study shows that Indians, Pakistanis and Bangladeshis differ in a wide range of coronary risk factors and combining their data is misleading

- Among South Asians, Indians were least and Bangladeshis most disadvantaged in a range of coronary risk factors. South Asians were disadvantaged in comparison with Europeans

- Future research and prevention strategies for coronary heart disease in South Asians should acknowledge a broad range of risk factors, the heterogeneity of these populations, linguistic and cultural needs, and environmental factors
As ethnic and racial differences are almost never demonstrably genetic, social and environmental differences are likely to be crucial. Our observations emphasise poverty (among Pakistanis and Bangladeshis), smoking (among Bangladeshis, Pakistanis, and European men), high blood pressure (among Europeans and Indians), obesity (in all groups), and a lack of exercise (in all groups). Our study supports a role for infant deprivation (South Asians were shorter, an indicator of poorer early life nutrition), ${ }^{24}$ central obesity and insulin resistance (all South Asians), abstinence from alcohol (especially Pakistanis and Bangladeshis), and chronic inflammation (higher white cell counts in Pakistani and Bangladeshi men; data shown on BMJ's website) as potentially important causes of coronary heart disease. ${ }^{26}$

Strategies to control coronary heart disease in South Asians should emphasise all important factors including social and environmental ones such as employment and poverty, propose linguistic and cultural adaptations, and consider the heterogeneity of Indians, Pakistanis, and Bangladeshis.

We thank Margaret Miller, Mavis Brown, Amanda McEwan, Heather Armstrong, Afroz Qureshi, Ayesha Motala, Kaushik Ramaiya, and Dilip Singh for help at the screening sessions; Peter Stevenson for both screening and analysis of electrocardiograms; Nan Keen for coding electrocardiograms; Denise Howel for statistical advice; David Whiting for writing the name search programme; Linda Ashworth for measuring insulin Sheinaz Mughal for advice; and Carole Frazer for preparing the manuscript. The interviews were done by a team of 20 interviewers, whom we thank. They were Jusna Ahmed, Mushtaq Ahmed, Shuhel Ahmed, Rafiqul Alam, Masooma Ali, Showkat Ali, Santokh Bamrah, Parul Begum, Manju Chandra, Malik Chaudhry, Shubh Ghai, Amarjit Ghura, Sultana Kimti, Raminder Pal Singh, Rajindar Ghura, Salma Hasan, Nasir Iqbal, Surbhi Khanna, Pardeep Lally, Rakesh Prasad, Arati Roy, Nasim Shafiq, Baldev Singh, Salah Uddin, Anita Sarkar, and Prehlad Kanwar.

Contributors: RB contributed to the study hypotheses and design, supervision of project, planning and interpretation of data analyses, and was the lead writer. NU and MW contributed to the study hypotheses and design, supervision, screening, planning, and interpretation of data.JY participated in management of screening in South Asian study, analysis of data, and drafting methods section. LW participated in preparation and analysis of data, and drafting methods, results, and tables of manuscript. KGMMA contributed to the study hypotheses and 
design and supervision of project. $\mathrm{JH}$ participated in development of study design, methods, and questionnaire for European study, management and screening of European population, and data coding. SP participated in screening South Asians, community liaison and recruitment to study, and data coding. NA contributed to development of South Asian questionnaire, translation, sampling, screening, recruitment, and data preparation. NU, MW, JY, LW, KGMMA, JH, SP, and NA commented on the manuscript. CT participated in screening, development of questionnaire, recruitment, and community liaison. BW managed and participated in screening for European and South Asian samples and helped with entry and preparation of data for analysis. DK participated in coordination of recruitment and data collection for the South Asian study, data analysis on response rates, and drafting text. AK participated in screening, development of questionnaire, community liaison, and recruitment. ML advised on biochemical methods, supervised laboratories doing biochemical tests, and had responsibility for $\mathrm{Lp}(\mathrm{a})$ lipoprotein assays. AT participated in the $\mathrm{Lp}(\mathrm{a})$ lipoprotein study and provided data and advice on $\mathrm{Lp}$ (a) lipoprotein. $\mathrm{RB}, \mathrm{GA}, \mathrm{NU}$, and $\mathrm{MW}$ are the study guarantors.

Funding: Barclay Trust, British Diabetic Association, Newcastle Health Authority, research and development directorate of the Northern Regional Health Authority, Department of Health, and British Heart Foundation.

Competing interests: None declared.

1 Balarajan R. Ethnicity and variations in mortality from coronary heart disease. Health Trends 1996;28:45-51.

2 McKeigue P, Sevak L. Coronary heart disease in South Asian communities. London: Health Education Authority, 1994.

3 McKeigue PM. Coronary heart disease in South Asians overseas: a review. J Clin Epidemiol 1989;42:597-609.

4 Bhopal RS. Several key facts need to be considered. BMJ 1996;312:375.

5 Shaukat N, de Bono DP. Are Indo-origin people especially susceptible to coronary artery disease. Postgrad Med J 1994;70:315-8.

6 Williams R, Bhopal R, Hunt K. Coronary risk in a British Punjabi population: comparative profile of non-biochemical factors. Int J Epidemiol 1994:23:28-37.

7 Nazroo J. The health of Britain's ethnic minorities. London: Policy Studies Institute, 1997.
8 Harland JO, Unwin N, Bhopal RS, White M, Watson B, Laker M, et al. Low levels of cardiovascular risk factors and coronary heart disease in a UK Chinese population. J Epidemiol Community Health 1997;51:636-42.

9 Unwin N, Harland J, White M, Bhopal RS, Winocour P, Stephenson P, et al. Body mass index, waist circumference, waist-hip ratio, and glucose intolerance in Chinese and Europid adults in Newcastle, UK. J Epidemiol Community Health 1997;51:160-6.

10 Coldman A, Braun T, Gallagher R. The classification of ethnic status using name information J Epidemiol Community Health 1988;42:390-5.

11 WHO MONICA Project. Geographical variation in the major risk factors of coronary heart disease in men and women aged 35-64 years. World Health $\operatorname{Org} Q 1988 ; 41: 115-38$.

12 Flegal KM, Carroll MD, Kuuczmarski RJ, Johnson CL. Overweight and obesity in the United States: prevalence and trends, 1960-1994. Int J Obesity Relat Metab Disord 1998:22:39-47

13 Bedfont Scientific. Operator's manual for mini and micro smokerlyzers. Upchurch: Bedfont Scientific, 1993

14 Rose G, Blackburn A, Gillum R, Prineas R. Cardiovascular survey methods. 2nd ed. Geneva: World Health Organisation, 1982.

15 Coombs M, Raybould S, Long CA. Index of deprivation. London: Department of Environment, 1992.

16 Modood T, Berthoud R, eds. Ethnic minorities in Britain. London, Policy Studies Institute, 1997.

17 McKeigue PM, Shah B, Marmot MG. Relation of central obesity and insulin resistance with high diabetes prevalence and cardiovascular risk in South Asians. Lancet 1991;337:382-6.

18 McKeigue PM, Marmot MG, Adelstein AM. Diet and risk factors for coronary heart disease in Asians in Northwest London. Lancet 1985;ii:108690.

19 McKeigue PM. Mortality from coronary heart disease in Asian communities in London. BMJ 1988;297:903-7.

20 Marmot MG, Adelstein AM, Bulusu L. Immigrant mortality in England and Wales 1970-1978. Causes of death by country. Studies on medical and population subjects. London: HMSO, 1984.

21 Nath BS, Murthy R. Cholesterol in Indian ghee. Lancet 1988;ii:39.

22 Pais P, Pogue J, Gerstein H, Zachariah E, Savitha D, Jayprakash S, et al. Risk factors for acute myocardial infarction in Indians: a case-control study Lancet 1996:348:358-63.

23 Fowler PBS. Diet and risk factors for coronary heart disease in Asians in north west London. Lancet 1985;ii:1363.

24 Barker DJP. Mothers, babies and disease in later life. London: BMJ Publishing, 1994.

25 Gupta S, de Belder A, Hughes LO. Avoiding premature coronary deaths in Asians in Britain. BMJ 1995;311:1035-6.

26 Mendall M. Inflammatory responses and coronary heart disease. BMJ 1998;316:953-4.

(Accepted 28 April 1999)

\title{
Influence of bacterial vaginosis on conception and miscarriage in the first trimester: cohort study
}

\author{
S G Ralph, A J Rutherford,J D Wilson
}

Department of

Genitourinary

Medicine, General

Infirmary at Leeds,

Leeds LS1 3EX

S G Ralph,

specialist registrar

J D Wilson,

consultant physician

Reproductive

Medicine Unit,

General Infirmary

at Leeds

A J Rutherford,

clinical director

Correspondence to:

J D Wilson

jdwilson@dunham.

freeuk.com

BMJ 1999;319:220-3

\begin{abstract}
Objectives To assess whether bacterial vaginosis affects the rates of conception and miscarriage in the first trimester.

Design Cohort study.

Setting Assisted conception unit of a teaching hospital in Leeds.

Participants 867 consecutive women undergoing in vitro fertilisation.

Interventions Screening for bacterial vaginosis with a Gram stained vaginal smear before egg collection.

Main outcome measures The presence of bacterial vaginosis or normal vaginal flora, and the rate of conception and miscarriage in the first trimester. Results 190 of 771 (24.6\%) women had bacterial vaginosis. No difference in conception rate was found between those women with bacterial vaginosis and those with normal vaginal flora: 61 women (32.1\%) and 146 of 493 women (29.6\%) respectively (relative risk $1.08,95 \%$ confidence interval 0.85 to 1.39 ; odds
\end{abstract}

ratio $1.12,0.77$ to 1.64$)$. However, 22 women (31.6\%) with bacterial vaginosis who conceived had a significantly increased risk of miscarriage in the first trimester compared with 27 women (18.5\%) with normal vaginal flora (crude relative risk $1.95,1.11$ to 3.42 ; crude odds ratio $2.49,1.21$ to 5.12 ). This increased risk remained significant after adjustment for factors known to increase the rate of miscarriage: increasing maternal age, smoking, history of three or more miscarriages, no previous live birth, and polycystic ovaries (adjusted relative risk 2.03, 1.09 to 3.78; adjusted odds ratio 2.67, 1.26 to 5.63).

Conclusions Bacterial vaginosis does not affect conception but is associated with an increased risk of miscarriage in the first trimester in women undergoing in vitro fertilisation, independent of other risk factors.

\section{Introduction}

Bacterial vaginosis is the most common cause of abnormal vaginal discharge among women of 